\title{
O MENINO QUE DESCOBRIU O VENTO
}

\author{
F. T. MARCELINO \\ Programa de Pós-graduação em Educação Profissional \\ Instituto Federal de Educação, Ciência e Tecnologia do Rio Grande do Norte \\ fabianatm@gmail.com
}

Submetido 29/12/2019 - Aceito 29/12/2019

DOI: $10.15628 /$ holos.2019.9350

Filme: "O menino que descobriu o vento"

Data de lançamento: 1 de março de 2019 na Netflix (1h 53min)

Direção: Chiwetel Ejiofor

Elenco: Maxwell Simba, Chiwetel Ejiofor, Aïssa Maïga

Gênero: Drama

Nacionalidades: EUA, Malawi, França, Reino Unido

O filme "O menino que descobriu o vento" é uma produção de 2019 da Netflix, que conta a história baseada em fatos reais do jovem William Kamkwamba. O filme é inspirado no livro de mesmo nome, escrito por William Kamkwamba e Bryan Mealer.

A história se passa no início dos anos 2000 em um vilarejo de Malawi, país localizado na África Oriental. O jovem William presencia simultaneamente o esforço dos seus pais de mantê-lo em uma escola particular, junto com as dificuldades de sua comunidade de manter a produção agrícola, tanto por causa das intempéries climáticas, quanto por causa da exploração gananciosa de empresas madeireiras, que prejudicam o solo. O local sofre com fortes chuvas por um período do ano, e a população tem o conhecimento, a partir da experiência dos líderes da comunidade, de que o desmatamento vai prejudicar a absorção da água pelo solo, afetando o plantio. As sementes que são plantadas antes das chuvas ficarão inundadas. E no período de seca subsequente, não terão condições de crescer. Em função deste ciclo climático natural, o plantio costuma ser feito apenas uma vez por ano, e com essa pequena produção os agricultores alimentam suas famílias durante o ano e adquirem com a venda dos grãos outros produtos de necessidades básicas, e assim se sustentam por um ano.

O governo entra em conflito com os líderes da comunidade para defender os interesses econômicos das empresas. Com a colheita prejudicada pela seca, William observa sua comunidade ser tomada pela fome, resultante da escassez de grãos e racionamento imposto pelo governo. $O$ caos instalado instiga o jovem a buscar alternativas para que seja possível um plantio durante o período da seca. A partir de sua curiosidade científica, William encontra na biblioteca da escola pista de que seria possível criar um moinho de vento para gerar energia para uma bomba d'água, visto que em pleno século XXI sua comunidade só tem acesso à energia através de pilhas portáteis de uso doméstico. Entretanto, a tecnologia necessária para a construção de um moinho já existe, e o menino se implica em descobrir como construir esse equipamento de forma acessível. Enquanto ele se sente tomado por essa curiosidade investigativa, ele é obrigado a se 
afastar da escola por falta de pagamento; entretanto, a professora responsável pela biblioteca consente que ele continue suas investigações.

O avanço das condições de vida precárias faz com que sua família volte a se ver na situação dos seus ancestrais de recorrer a orações para amenizar o sofrimento causado pela fome, apesar deles entenderem que há muito mais do que planos divinos subjugando-os. Essa compreensão se mostra principalmente representada pela mãe de William, Agnes Kamkwamba, que não aceita o apelo do seu esposo Trywell em recorrer ao plano divino para pedir ajuda. Agnes também é consciente da importância de ambos os filhos irem à escola para serem independentes, entretanto precisa lidar com as dificuldades concretas que a impedem de enviar a filha Annie, mais velha que William, à universidade, como prometido. Diante desta realidade dura, Annie se vê na posição difícil de aceitar o pedido do seu namorado, o professor de William, para que fujam juntos da seca em direção à área urbana. Annie sabe que fazer isso traçará o seu destino como dona de casa e mãe de família. Apesar da relutância, ela aceita essa opção como alternativa para investir no esforço investigativo do seu irmão, fugindo com seu namorado em troca do dínamo que ele utiliza para criar energia elétrica para a lâmpada de sua bicicleta.

Com o dínamo, material de sucata e ajuda de amigos que acreditam em sua teoria de utilizar o vendo para fazer chover, William passa a fazer experimentos para comprovar sua ideia de transformar energia mecânica em elétrica. Com os avanços dos seus experimentos, ele fica cada vez mais confiante, entretanto esbarra no ceticismo do seu pai, já descrente depois de tanto sofrimento. William consegue a confiança do pai, que é necessária para agregar a comunidade em torno da construção do moinho para a comunidade. Assim, ele consegue construir o moinho com sucata e retirar água de poço, viabilizando a produção agrícola fora do período habitual.

William posteriormente se formou com bolsa de estudos em engenharia nos Estados Unidos.

O filme é muito comovente ao mostrar com fidedignidade que a fome ainda é uma sombra que atinge a humanidade em pleno século XXI, embora haja tecnologia necessária - e simples, e barata - para combatê-la. O que ainda falta é interesse econômico e político efetivo para intervir nessa realidade, bem como envolvimento internacional para garantir o acesso a todo ser humano a direitos básicos como alimentação, moradia, educação. A implicação de algumas pessoas em investir na educação do jovem William infelizmente não se observou em relação a investimentos econômicos e políticos para a melhoria condição de vida da sua comunidade, por exemplo.

Relacionando o filme à leitura de "Um discurso sobre as ciências" (SANTOS, 2008), penso que, embora a postura científica de William possa ser semelhante à dos cientistas experimentais tradicionais, a sua história de vida e seus interesses no resultado de suas descobertas me faz refletir sobre sua história como um possível exemplo do que Santos (2008) intitulada de paradigma emergente da ciência. Da mesma forma, o fato de que todo o esforço do jovem se resume a aplicar sem recursos um conhecimento já existente, porém inacessível onde ele vive, me faz ponderar que é chegada a hora em que a ciência precisa sair do seu lugar distante e imparcial para fazer a diferença.

"Em termos científicos vivemos ainda no século XIX", disse Santos (2008), contudo penso que não só em termos científicos, mas também em termos de lidar com os fenômenos naturais aos quais a ciência moderna tanto se dedicou a conhecer e controlar. Santos (2008) observa que 
"é muito diferente perguntar pela utilidade ou pela felicidade que o automóvel me pode proporcionar se a pergunta é feita quando ninguém na minha vizinhança tem automóvel, quando toda a gente tem exceto eu ou quando eu próprio tenho carro há mais de vinte anos". A postura científica hoje vai (ou precisa) ir além da simples curiosidade investigativa inócua; há implicações complexas envolvendo as condições sociológicas e psicológicas no ato de perguntar. A industrialização da ciência resultou na implicação desta com interesses do poder econômico, social e político.

William, em seu esforço para descobrir uma forma de melhorar a vida de sua família e comunidade, caminha em direção a um paradigma científico diferente. Sendo nossa sociedade contemporânea uma sociedade revolucionada pela ciência, esse nova paradigma que revolucionará a ciência caminha para a emergência de um paradigma não apenas científico, mas um paradigma social - o paradigma de uma vida decente. A distinção entre sujeito e objeto se confundem, a partir dos interesses e implicações do pesquisador William na sua pesquisa. Uma concepção humanística da ciência me parece o mais próximo da percepção de William sobre o que ele pode trazer com a inovação tecnológica que ele propõe. A persistência dele, em conjunto com as suas observações sobre as pessoas e a terra onde vive, lembra o que Santos diz sobre o senso comum, que ele "é conservador e pode legitimar prepotências, mas interpenetrado pelo conhecimento científico pode estar na origem de uma nova racionalidade".

"O progresso das ciências e das artes contribuirá para purificar ou para corromper os nossos costumes?", perguntou-se Rousseau, segundo Santos (2008). A resposta seria não. Mas, a partir da reconfiguração da ciência em um paradigma diferente, seria possível ao menos caminhar no sentido aproximar nossos costumes e o conhecimento científico, ambos seguindo neste caminho, juntos, lado a lado, com o propósito de construir uma ciência que tenha em sua essência uma concepção humana em seu observar, contemplar, agir, produzir.

"O menino que descobriu o vento" é uma história necessária para refletir sobre o método científico e as implicações da ciência em contextos regionais, políticos, históricos e sociais. Estudantes e docentes de todos os níveis de ensino, e profissionais da pesquisa de qualquer área de conhecimento podem encontrar ao assistir este filme uma excelente oportunidade para pensar sobre o lugar da ciência nos dias de hoje.

\section{REFERÊNCIAS}

SANTOS, B. S. (2008). Um discurso sobre as ciências. São Paulo, Cortez. 